\title{
Interleukin-18-Binding Protein
}

National Cancer Institute

\section{Source}

National Cancer Institute. Interleukin-18-Binding Protein. NCI Thesaurus. Code C118906.

Interleukin-18-binding protein (194 aa, $21 \mathrm{kDa}$ ) is encoded by the human IL18BP gene.

This protein plays a role in binding to and sequestration of interleukin-18. 